This item was submitted to Loughborough's Research Repository by the author.

Items in Figshare are protected by copyright, with all rights reserved, unless otherwise indicated.

\title{
Transnational employee voice and knowledge exchange in the multinational corporation: The European Company (SE) experience
}

\author{
PLEASE CITE THE PUBLISHED VERSION
}

https://doi.org/10.1177/0018726720905351

\section{PUBLISHER}

SAGE Publications

\section{VERSION}

AM (Accepted Manuscript)

\section{PUBLISHER STATEMENT}

This paper was accepted for publication in the journal Human Relations and the definitive published version is available at https://doi.org/10.1177/0018726720905351. Users who receive access to an article through a repository are reminded that the article is protected by copyright and reuse is restricted to non-commercial and no derivative uses. Users may also download and save a local copy of an article accessed in an institutional repository for the user's personal reference.

\section{LICENCE}

CC BY-NC-ND 4.0

\section{REPOSITORY RECORD}

Fiedler, Antje, Catherine Casey, and Benjamin Fath. 2020. "Transnational Employee Voice and Knowledge Exchange in the Multinational Corporation: The European Company (SE) Experience”. Loughborough University. https://hdl.handle.net/2134/11931357.v1. 


\title{
Transnational employee voice and knowledge exchange in the multinational corporation: The European Company (SE) experience
}

\begin{abstract}
The European Company (SE) regulations include the highest mandatory provision for negotiation of transnational employee voice. What are the effects of transnational employee voice, enacted at works council and board levels, on knowledge exchange within the multinational corporation? This qualitative study of globally active SEs incorporated under the SE regulations that have 'dual-forum' transnational employee voice addresses that research gap. Our main contribution reveals that, over time, transnational employee voice facilitates multifaceted knowledge exchange, both widening the platform and strengthening relations for intra-MNC collaboration. Alongside expressing labour interests as intended, dual-forum transnational employee voice stimulates managers and employees to develop mutually beneficial competencies and trust. These aid multilateral knowledge exchange. That knowledge, which includes factors affecting employees and quality of organizational and work life, also includes insights into country-specific market, industrial, and operational issues. Importantly, dual-forum transnational voice fosters development of a participatory culture across the MNC. Robust multifaceted knowledge exchange generates better-informed and more productive decision-making that yields plural socio-economic value.
\end{abstract}

Keywords: Multinational corporation, MNC, knowledge exchange, knowledge sharing, transnational employee voice, trust, European Company, Societas Europaea, European Work Council, trade unions

\section{Introduction}

Transnational employee voice refers to representative employee interest expression in multinational companies (MNCs) that is inclusive of, and drawn from, employees across 
multiple countries where the MNC operates. This subject increasingly attracts research attention, principally in regard to protection and advancement of employees' interests (De Spiegelaere and Jagodziński, 2015; Hann et al., 2017; Keller and Werner, 2012). Transnational employee voice is at origin an institution intended, according to the Council of the European Union, to 'promote the social objectives of the European Community' (Directive 2001/86). From a labour interest perspective, transnational employee voice is a hard-won and often tenuous and fraught accomplishment. A rights and benefits interest is therefore, unremarkably, of principal emphasis. But the role of transnational employee voice in generating knowledge and capabilities development with potential multilateral and multifaceted benefits warrants investigation.

Many companies emphatically pursue economic and market objectives and regard labour interests and demands as a cost to be managed. Many are reluctant to consider the wider utility and value of facilitating employee voice and social rights. Yet, at the same time, MNCs are highly reliant on skilled workers and efficient transnational, cross-subsidiary knowledge flows and exchange. Knowledge exchange is a core shared interest among actors in an economic organization. Transnational employee voice provides a formal resource and channel of knowledge and interest expression. We propose that the social character of employee voice inclines it to various and unpredictable outcomes and generativity. The interaction of labour-interested transnational employee voice with management-interested operational knowledge exchange may yield socio-economic value.

A stream of research addressing the employment relations benefits and politics of employee voice has pointed to potential or actual mutual benefits of formal employee voice practices for both labour and company interests (Boxall and Macky, 2009; Budd et al., 2010; Kim et al., 2010; Kochan and Osterman, 1994; Lavelle et al., 2010). Some have proposed the importance of the 'soft power' of employee participation that exerts constraint on firms' market imperatives and ensures the salience of labour interests (Casey et al., 2016). But 
results are inconclusive and, for labour actors, typically more worrisome than encouraging. Decline or manipulation of employee voice practices is a recurrent concern (Baccaro and Howell, 2017).

Nonetheless, in the case of the European Union (EU), formal statutory provisions aim to protect the social interests and rights of employees across MNCs' entities in the EU. Notably, provisions for transnational employee involvement (i.e. representative employee influence in company decisions), first introduced in the 1990s, entail employee interest expression that is scarcely available in the rest of the world. The effectiveness of these transnational institutions is still emergent. In contribution to research on that effectiveness, we enquire in this article into effects of transnational employee voice in regard to the intersection of labour-interested transnational employee voice with management concerns for employees to share knowledge that facilitates and enhances organizational and operational activity. Our research questions ask: what are the effects of transnational employee voice that includes both works councils and transnational employee board-level representation on knowledge exchange processes? What do they yield over time?

We pursue these questions by investigating the provision of transnational employee voice in the European Company (Societas Europaea, SE). We focus on the SE because SE regulations include the highest mandatory provision for negotiation of transnational employee involvement, including transnational board-level employee representation and transnational works councils. The SE formally possesses potential to provide relatively extensive forums of transnational employee voice. Knowledge about potential multifaceted benefits of relatively robust transnational employee voice is scarce.

Much debate on transnational employee voice arrangements occurring in company operations raises concerns in regard to company power to circumvent or weakly adopt employee voice practices and deflect trade union demands (Baccaro and Howell, 2017; 
Keller and Rosenbohm, 2019; Pulignano and Waddington, 2019). We are cognisant of those concerns. We also contribute to debates by bringing to light nuances and human relational factors that are stimulated among actors within organizations in the course of enacting transnational employee voice in MNCs. Alongside employee rights interests it casts light on ways - both longitudinal processes and effects - in which transnational employee voice builds capacity for multilateral (vertical and horizontal) knowledge sharing across borders with diverse utility. The article demonstrates that SE transnational employee voice, when effectively enacted at works council and board levels, generates expansive capacity for intraMNC collaboration. SE transnational voice stimulates managers and employees to develop competencies, including trust, that facilitate multilateral knowledge sharing toward development of a shared participatory culture across the MNC. The knowledge shared includes insights into country-specific market and industrial issues, factors affecting employees and quality of organizational and work life. Importantly, such knowledge contributes to company strategic decisions of mutual benefit to management and workers.

Below, we briefly review the literature on transnational employee voice in European MNCs, and knowledge sharing in MNCs. That is followed by the methodology and findings. We then discuss our contributions, and limitations, before a brief conclusion.

\section{Transnational employee voice in European MNCs}

Key developments in formal establishment of transnational employee voice in European MNCs arise predominantly from institutionalization of European works councils (EWCs). The 1994 European Works Councils Directive, recast in 2009, established the first mandatory transnational industrial relations institution applicable to MNCs operating in the European Union. That was followed in 2001 by the European Company Statute and Directive and the Information and Consultation Directive in 2002. The 2003 Statute for a European Cooperative Society and the 2005 Cross-Border Mergers Directive included provisions for 
employee board-level representation largely based on the SE Directive, but due to longer history, availability of rich data, and greater salience, much attention is accorded to EWCs.

Robust debate on the EWC over 20 years (Hann et al., 2017; Kerckhofs, 2015; Lecher et al., 2002; Waddington, 2010; Whittall et al., 2007) concerns its successes, failures and challenges. EWCs are widely recognized as important to European social dialogue and improve transnational participation, information and consultation. At the same time, researchers point to considerable variety in EWC experiences and effectiveness. Many MNCs have been slow to set up EWCs. Sometimes contentiousness and stalled negotiations have resulted in European-level trade unions taking cases to the European Court of Justice (Whittall et al., 2009). Once established some EWCs remain rudimentary with little or no substantive influence (Marginson et al., 2013). Others are dominated by particular national actors with internal conflicts among representatives and little transnational inclusion (Mählmeyer et al., 2017). Some EWCs are effective in achieving transnational employee participation with influence in company decisions (Hann et al., 2017; Hertwig et al., 2011; Waddington, 2010). More generally, researchers conclude that erratic and disappointing development shows EWCs remain a contested institution with many being utilized predominantly to employer advantage (Pulignano and Waddington, 2019).

Managers may utilize EWCs for communicating on strategic issues, legitimizing organizational change and circumventing industrial conflict (Lippert et al., 2014). EWCs with a stable information structure and productive management relationships gain legitimacy and increase knowledge exchange across borders and between subsidiaries and business units (Lecher et al., 2002; Waddington, 2010; Whittall et al., 2007). While these may favour management interests, researchers note that continual networking within EWCs of union officials and transnational employee representatives contributes to trust building and knowledge sharing among diverse actors (Marginson et al., 2004; Platzer and Rüb, 2014). That encourages actors to transcend national interests and foster wider cooperation (Cavallini 
et al., 2015). These findings point to wider and potentially mutual benefits to employees and company actors of effective voice practices.

In regard to the SE, the Directive (2001/86/EC) requires that employers negotiate arrangements for formal employee involvement. This must occur on establishment and there is no minimum employment threshold. The required arrangements include forming an SE European Works Council (hereafter SEWC) with, at minimum, information and consultation rights, and negotiation of transnational employee representation at board level. SEWCs operate similarly to EWCs (De Spiegelaere and Jagodziński, 2015). Most SEs are German establishments and they have to date typically retained their pre-SE incorporation employee voice practices according to German regulation (Rosenbohm, 2013; Weiß, 2016). Most SEWCs officially can 'give opinion/comment', 'initiate projects', 'make recommendations', engage in 'negotiations' and aim to 'reach consensus' and possess greater competencies on employment issues of redundancies, job transfers and skill development systems (De Spiegelaere and Jagodziński, 2015). Relatively few SEs have agreed transnational board-level employee representation (Cremers et al., 2013) but where established, the SEWC typically exceeds information and consultation rights. Where SEWCs elect transnational board-level employee representation a direct link is forged that aids coordination (Waddington and Conchon, 2017).

The influence of transnational board-level employee representation on company decisions ranges from very little (Carley, 2005) to variable (Gold, 2011) and sometimes significant (Waddington and Conchon, 2017). Some research indicates that input from transnational board-level employee representatives (TBLERs) into board discussions can mitigate internal agency problems (Fauver and Fuerst, 2006) and enhance knowledge flows across subsidiaries (Casey et al., 2016; Gold, 2011). Waddington and Conchon (2017) observe SE employee board-level representation as developing some unique patterns beyond 
merely extending national practices and features. This suggests that the relationships between transnational employees, union experts and managers evolve over time. But how they evolve, and how they achieve compatibility and mutual benefits, is unclear. We return to this point below; first, brief remarks on knowledge exchange in the MNC are pertinent.

\section{Knowledge exchange in MNCs}

A field of research in international business and management addresses the transfer, flow and optimal utilization of organizational and operational knowledge across geographically and culturally dispersed units of MNCs. Attention frequently focuses on relations between headquarters and subsidiaries and among subsidiaries (Ahlvik and Björkman, 2015). Researchers identify barriers and frictions in transnational knowledge transfer that include institutional divergence on many dimensions and at multiple levels, from national macroeconomic and business systems to interpersonal behavioural norms. Miscommunications and misunderstandings arise from diverse languages and cultures (Bhagat et al., 2002; Harzing and Pudelki, 2013; Welch and Welch, 2008) and frictions arise from divergent management practices and ideologies (Hughes et al., 2017; Mudambi and Swift, 2011; Tempel et al., 2006), and political processes (Ferner et al., 2012; Morgan and Kristensen, 2006) both within the MNC and between national business systems (Edwards et al., 2013). A stream of research addresses the role of HRM practices and capabilities development (Ahlvik and Björkman, 2015; Belizón, 2018; Edwards and Edwards, 2015; Minbaeva et al., 2003) that affect MNC organizational and operational effectiveness.

Across these concerns, researchers identify the role of trust, including employeemanager relationships, in facilitating information and knowledge exchange (Lee et al., 2010; Nahapiet and Goshal, 1998; Wang and Noe, 2010). Mistrust hinders transnational communication, collaboration and knowledge sharing (Geppert and Williams, 2006). Trust includes affective and cognitive dimensions (Adler, 2001; McAllister, 1995) that dynamically 
co-exist. Affective trust occurs on a personal level built through social interactions and based on emotional factors (Chua et al., 2008). Cognitive trust concerns appraisal of past performance and professional knowledge of another (Chowdhury, 2005). Affective trust comes to the fore in facilitating interpersonal knowledge sharing, while cognitive trust among actors enhances the organizational learning environment (Martin-Perez and Martin-Cruz, 2015; Swift and Hwang, 2013). Questions on how that trust is generated remain puzzling. In regard to transnational knowledge exchange, researchers observe the role of skilful individuals in navigating intracompany tensions and barriers. Individuals use personal, linguistic, communication, cultural and other relational skills to aid information exchange, resolve conflicts and build trust (Barner-Rasmussen et al., 2014; Harzing and Pudelki, 2013). They form and strengthen networks, help organizational units cooperate (Grigoriou and Rothaermel, 2014) and coordinate goals between managers and employees (Schotter and Beamish, 2011). Motivation to share knowledge is affected by the quality of organizational culture, inter-actor trust, and employee well-being (Geppert and Williams, 2006; Minbaeva et al., 2003; Peltokorpi, 2015). Seldom studied, however, is the role of formal transnational employee voice, which is primarily instituted to protect employee rights and interests, in affecting various intra-MNC knowledge exchange.

Following our review of the transnational voice and knowledge exchange literature, we propose that close attention to the inter-relations of employee voice practices with processes of operational knowledge exchange among company personnel may bring to light qualitative factors and dynamics of exchange. In organizational working life, employees, in possession of occupational skills, competencies and pride, possess two-fold interests: those of protection of their employee rights, and those of mutually valued contribution of their expertise (Casey, 2009). That is, workers typically want to contribute their occupational and human resources to productive goals valued by the company, and secure employee esteem 
and rights at the same time. Effective and respected transnational employee voice practices propose to enhance the latter and may simultaneously facilitate and enhance productive knowledge flows.

\section{Methodology}

To investigate the effects on intra-MNC knowledge exchange of transnational employee voice that combines works councils with transnational board-level employee representation, we conducted an empirical study of 13 SEs in operation in 2014. All of the SEs are headquartered in Germany except for one headquartered in Austria. At mid-2014, there were 2150 SEs in 25 of the 30 European Economic Area states, but most were irregular registrations (Stollt and Kluge, 2011). We selected cases using three criteria. First, we studied exclusively 'normal' SEs: those actually operating and employing people. Second, we focussed on SEs that have established not only SE works councils (which are mandatory) but also transnational board-level employee representation (which is subject to negotiation). These remain a rare phenomenon, with by mid-2018 only 73 existing SEs having agreed employee board representation (Keller and Rosenbohm, 2019). Third, we focussed on large companies, namely those with more than 3000 employees, as we expected these to face the greatest challenge in transforming well-established national employee voice into transnational employee voice. Using the European Trade Union Institute (ETUI) database and our own research on company documentation, we identified 21 large, normal, dual-forum SEs. Of these, 13 agreed to participate in our research.

We conducted 45 in-depth interviews. Interviewees worked in Germany, Italy, Austria, the Netherlands and the United Kingdom. They comprised CEOs and senior managers, TBLERs, SE works council members, trade union officials and expert informants. The latter two groups were invited as they typically perform an important role in establishing the SE and continual advice of employee representatives. We conducted the interviews (35- 
75 minutes) in person or by telephone in the participant's preferred language. Interviews enquired about participants' role, involvement in and experience with transnational employee voice, including SE works council and board-level representation, and the aims they perceived each company had in adopting the SE form. We asked about objectives, outcomes, interactions between managers and TBLERs, and barriers to and facilitators of collaboration. The semi-structured interview protocol was adjusted for participants' different roles (Creswell, 2012). The interviews were recorded and transcribed.

For 12 of the 13 companies at least one management and one employee representative, and at least one board member, were included. Industries spanned automotive, manufacturing, insurance, electric utility, market research, construction, retail, chemicals and medical care. By sampling multiple perspectives, the potential informant bias can be reduced (Martin and Eisenhardt, 2010), enhancing the credibility of the findings (Langley and Abdallah, 2011). Table 1 profiles the SEs and the interviewees' positions. As the data in the table demonstrates, these MNCs have significant global reach and influence with at least $40 \%$ of their employees are outside their home country.

\section{INSERT TABLE 1 ABOUT HERE}

We analysed and coded the interviews, identifying patterns, similarities and differences. Although we collected all the interview data in a single period of eight months, we analysed it longitudinally, yielding our three-phase findings. To understand how transnational employee voice evolved over time, we enquired into the sequence of events for each SE; how relationships between different key actors changed over time and how it affected knowledge sharing. Respondents reported their perceptions on key themes, such as mechanisms to establish transnational employee voice, challenges and perceived outcomes. We returned to transcripts iteratively (Eisenhardt and Graebner, 2007) to reach saturation in coding (Urquhart, 2013). First, 'open coding' captured themes from interviews about how the establishment of the SE affected employee voice in the MNC (first-order categories) (Corbin 
and Strauss, 2008). The emerging themes were constantly compared and contrasted to identify broader, second-order themes (Gioia et al., 2013). Table 2 illustrates themes selected from all phases with quotations from three perspectives: employees, unions and managers. It shows barriers, change mechanisms to overcome them and outcomes.

\section{INSERT TABLE 2 ABOUT HERE}

Second, 'axial coding' brought out patterns of interactions and relationships between the categories (Corbin and Strauss, 2008). Finally, 'selective coding' discerned core themes and their relationships including temporal patterns in how the SE was implemented. To discover mechanisms underlying knowledge sharing, we compared and contrasted our evolving findings with the literature. We studied company documents and extant SE case studies to triangulate the qualitative interviews and obtain a more fine-grained understanding of the research context. Based on this analysis, we derived a process model that describes the typical process of raising transnational employee voice in SEs through three phases and their effects on knowledge sharing.

\section{INSERT FIGURE 1 HERE}

\section{Findings}

Taking a processual and longitudinal approach, our analysis of the data discerned three phases that depict the evolution of relationships between transnational employees, union actors and management actors over time: 1) pre-SE and anticipations of the SE; 2) the establishment and working of the SEWC; and 3) the SEWC's articulated relations with the board. Phases 2 and 3 thus overlap. Figure 1 traces these phases at three levels: national, SEWC and board.

\section{Phase 1: Employee voice and SE initiation}

Prior to establishment of the SEWC employee voice was notably unevenly distributed and practiced across the MNCs. Only employees from headquarters were represented on the 
board. Despite headquarters' long history of transnational board-level employee representation, some subsidiaries had no national works council and/or access to a transnational one. Therefore, transnational employees often had few or no linkages and their representatives had never met before SEWC negotiations. A manager explained: 'We had an EWC before the SEWC. It was not fully involved in cross-border projects' (\#2- HR Director). Transnational employees had very little voice and opportunity to exchange knowledge. PreSE works council, the variations between different national employee voice provisions obstructed transnational employee voice development. For instance, respondents reported that subsidiaries often had a mainly adversarial voice culture whereas headquarters displayed a more collaborative culture.

Employee representatives entered SEWC negotiations with trepidation. A union lawyer noted: 'some representatives from smaller countries ... don't know what employee voice means, what opportunities it can create, what rights they have, and how it relates to the company' (\#42- Trade union lawyer). Others feared the SEWC would take subsidiaries' autonomy or headquarter representatives would dominate negotiations. Some worried that converting to an SE might undermine relations with management. A union representative observed:

There are very different types of employee voice in Europe and different processes of selecting employee representatives. There are very different people coming together who, from a German perspective, are not necessarily suitable representatives. Trust in the [negotiating] committee can be weak. (\#29- Trade union, board)

Moreover, the prospect of board participation makes the SE framework more contestable. Many SEWCs elect TBLERs who share their knowledge and perspectives with managers. Following transnationalization, employees from headquarters had to surrender some seats to transnational colleagues who lacked board-level experience. Some shared a union expert's 'concern that transnationalization could weaken employee voice on the 
board... A reliable, agreed representation will become more difficult' (\#44- EU trade union official). Transnational employees noted the duties and torn loyalties board membership would entail. A lawyer explained that in some EU member states:

There are strong reservations against [transnational board-level employee representation] because it means representatives may be involved in unpopular decisions. It is unthinkable for a French or Spanish colleague to be part of a decision to close down a business unit. [So] they don't want to be part of the board. (\#42Trade union lawyer)

Yet, many managers acknowledged that the pre-SE voice structure, dominated by headquarters employees, did not reflect the reality of the MNC and impeded knowledge sharing. One executive manager explained:

Our European market share has been strong for some years, so we were already a European company. A single country dominating this European company [in] employee voice no longer reflected our structure. (\#6- CEO/Chair of board)

\section{Phase 2: SE works council and transnational knowledge sharing}

Negotiations with employer and employee representatives aim to produce a firmspecific agreement on transnational employee voice including capacities of the SEWC and board representation. Our data identifies the significance of key actors in enacting agreed arrangements and facilitating knowledge sharing. Three aspects were significant: 1) key individuals forging personal (affective) trust during negotiations; 2) skilled individuals' guidance and experience on augmenting effective employee voice practices in subsidiaries to achieve transnational compatibility; and 3) joint actors hailing early successes of the SEWC to build legitimacy.

Firstly, a manager reported that negotiations in his company were marred by tensions among different Polish trade unions. An individual Polish employee deliberately worked to 
win trust and build unity on the negotiating committee. Through interpersonal interactions and emphasizing shared interests, disparate views shifted toward sufficient consensus for decisions to be made. In another example, an executive manager who had assisted on other SE transformations as a lawyer was strategically hired as HR Director to support the MNC's transformation. His interventions included promoting informal gatherings, like shared dinners and city tours, which cultivated vital personal affective trust among representatives. The importance of key individuals during initial negotiations in building employee-manager relations further emerged from an executive manager and an HR Director of separate SEs, who each praised their SEWC chairs:

$[\mathrm{He}]$ is well connected and well respected by the senior management team. As a result, if the SEWC makes a request we usually comply [...]. (\#2- HR Director) The [SE] works council chair was very charismatic and had good access to the different international representatives. He was well respected and a good moderator. Without him, the establishment would have been very difficult. (\#41- Executive legal) On the second factor, the guiding action of skilled individuals enabled identification and harnessing of actors' experience and knowledge of employee voice at national or local levels to highlight effective practices and processes for sharing across different countries. They also identified where direct transfer between countries with divergent practices was inappropriate or counterproductive. Skilled and experienced employee representatives, unions and managers pooled ideas and experiences. Their initiatives included:

We've now established country meetings in the subsidiaries. Before and after SEWC meetings, employee representatives meet with national works council and HR managers, exchange knowledge about various issues and discuss how change projects can be implemented in the specific country. (\#12- Employee representative) 
Union representatives with access to specific knowledge on the legal provisions of other SEWCs presented this knowledge to employee representatives at workshops or SEWC meetings. For instance, they explained 'what we [employees] have to do, the different national legal systems and so on' (\#17- Trade union, board). By considering 'the different national systems they found a compromise agreed by all countries using the experience of the representatives in negotiations' (\#12- Employee representative, SEWC). Such knowledge exchange exposed employees with particular experience to more expansive potential in exercizing voice:

During SE works council meetings, people listen and are surprised about the level of influence works councils have in Germany or in Austria. They want to know how this can be achieved. (\#17- Trade union, board)

We have an opportunity to get a new perspective. For example, we have a colleague from Poland who offers a different view, and this opened our minds to take a wider perspective and consider the roles other countries play. (\#40- SEWC, board)

The third role of key actors entailed communicating early achievements of the SEWC. That helped legitimize and encourage transnational employee voice in subsidiaries. Examples included SEWCs preventing redundancies or negotiating benefits readily recognized by employee representatives. Success stories also inspired trust to further engage and share knowledge. Significantly, such stories often went beyond the constituencies of the SEWC, whose legal obligations only included cross-national issues. In several MNCs the SEWC secured labour-interested benefits in individual countries with national subsidiaries. Examples included a national works council, company-provided childcare, education and training, and support in a crisis. One SEWC representative reported: 'In Greece, we had a crisis, and the SEWC was trusted with discussing it...' and so, 'even though the revenue had 
halved, no redundancies were made. So we are not just focussing on cross-border issues, we also look at specific country cases' (\#35- SEWC).

Furthermore, when SEWCs relay knowledge to national works councils, national employees gain additional valuable information from management 'which they could have never obtained' (\#1-SEWC, board). For instance, an employee

[...] at plant level does not realize how much knowledge is shared on the SEWC. But of course, he notices positive change in his [subsidiary] company. The national works council can gain benefits through the effects of the SEWC (\#22- HR Director).

Overall, through augmenting employee practices to improve transnational compatibility, fostering inter-personal trust, sharing stories of favourable outcomes, solidarity and camaraderie, key actors' collective trust in the SEWC had been built. That in turn facilitated further knowledge sharing and collaboration. Over time, new routines and structures were created that fostered favourable transnational relations.

Trust is becoming stronger... Everybody now knows the basic facts, the issues ... There is some routine now that helps to find a shared position much faster. Through this routine they gain more strength. (\#23- Trade union, board)

A CEO reports what he deems the benefits of a 'shared participatory culture of employee voice' (\#6- CEO/Chairman of board) that go beyond employee interest and improve manager-employee relationships. In sharing knowledge and concerns they recognize shared interests.

Importantly, actors report transnational employee voice also enhances operational knowledge flows and trust in the MNC. For instance, an SEWC representative illustrated the intermingling of knowledge and interests in knowledge transfer. His SEWC reports and shares knowledge 'about current technical issues... We have a priority email to communicate urgent incidents, such as machine failures. We ask across the MNC [for expert advice] to fix 
it' (\#35- SEWC). Respondents noted that highly skilled employees like to share their knowledge with similar others across the company group. This suggests employee interests are multifaceted and interwoven.

A further point refers to an MNCs' cultural diversity which extant literature has noted as historically a source of misunderstanding, distrust, conflict and barriers to knowledge sharing. Actors report that SEWCs and TBLERs enable more congenial inclusion and positive recognition of cultural diversity. It becomes a source of high performance, fostering organizational learning and motivation. Transnational personnel 'learn from each other and take things that are working well back home' (\#41- Executive manager - legal). A board chair reports:

In many ways, it's about psychological and cultural change. Employees can say, we belong together ... as a result, the motivation, organizational integration and solidarity can be strengthened. (\#13- CEO/Chairman of board)

Managers reported that the SEWCs influenced organizational change and restructuring in $\mathrm{MNCs}$, like relocations, operational expansions and socially responsible redundancies. A manager reports that their 'SEWC is involved in capital investment planning' (\#22- HR Director). Another respondent reported a subsidiary company facing a severe financial crisis. A plan by the SEWC, with managers, 'to help highly qualified workers shift jobs across countries (\#11- SEWC, board) ensured highly skilled employees were retained within the company'.

The SEWC achieves mutual recognition of these bundles of interests and fosters a collective social response to problems such as jobs and skills retention. 
Phase 3: Transnational employee voice, knowledge sharing and board relationships

In the third phase the board representatives and the SEWC forged stronger links, ensuring knowledge from the board was shared with the SEWC within its legal boundaries. In our cases TBLERs also sat on the SEWC. Respondents said two main factors increased effective board representation: TBLERs building cognitive trust with managers; and gaining competencies to effectively straddle their sometimes conflicting roles or loyalties. Cognitive trust is won, for instance, as TBLERs develop skills in accounting and company law, 'to read financial statements presented according IFAS accounting standards' (\#43- European trade union expert). Company and union respondents note that where industries require board members to gain certified competencies companies paid for the training. Mutual benefits are expected. Meanwhile, at SEWC level European unions provide training, including disseminating privileged knowledge and expertise gained through their transnational networks: 'They share this knowledge between EWCs in the same industry as well as different industries' (\#18- Trade union actor).

Transnational labour-interested knowledge enables TBLERs to influence companies' decision-making on restructuring projects. But the weight of that influence, actors report, depended on managers' trust of TBLERs. To strengthen influence between the SEWC and managers, employee representatives must nurture a constructive relationship with managers. One executive manager, who directed human resources, said:

[Employee representatives] can consult on major strategic decisions, but from a legal point of view they have no 'hard' participation rights [to approve decisions]. It is important that they gain the trust of the executive team. (\#2- HR Director) Importantly, the trust accorded TBLERs enables them to influence employee and social issues. Trust with managers takes more than good personal relationships. According to executives, employee representatives' input must add value to board decision-making and be constructive and fair, while representing their constituency. TBLERs must ask hard questions 
that challenge managers' current thinking. One CEO uses the term 'sparring partner' to describe the ideal board-level employee representative; 'they need to provide critical but constructive input' (\#13- CEO/ Chairman). If employee representatives can win managers' trust, the SEWC's influence may surpass legal obligations. For example, an HR director reports that the company needed to undertake 'a very large restructuring project of a subsidiary due to new regulations. It did not directly affect employees, but we involved them. We involved the SEWC on changing the business model of the subsidiary' (\#2- HR Director). In such actions managers also foster more trust among labour actors.

The second factor influencing how effective TBLERs were on the board was how well they learned to straddle their dual (or multiple) roles and loyalties: to their SEWC electors, their transnational constituency, national subsidiary workforce peers, and managers as fellow board members. The SEWC has to be strategic about board appointments:

We have a very sophisticated system to ensure that each region is represented, including the headquarter and its subsidiaries. We select the six seats based on the consideration that each region somehow has access to the board. We don't elect representatives on whether we like them but based on how they can represent a region. (\#44- EU trade union official)

I suggested that it wouldn't be wise if one country has more than half the seats.... The employee representatives from the headquarter country then agreed to limit their own positions to less than half. (\#35- SEWC)

To be effective on the board, TBLERs had to 'learn how to wear different hats' (\#44- EU trade union official), making difficult decisions and keeping some information confidential while also connecting the SEWC to the board. Legal training was considered helpful to understand 'what is allowed or not allowed', but it also posed a personal and interpersonal challenge. For example, TBLERs sometimes reported pressures from the national works 
council to disclose board information without the required management approval. Moreover, TBLERs said the local management 'do not want to allow much time for their workers to be in these kinds of [transnational] bodies' (\#35- SEWC). Experienced transnational actors endeavour to assist with these role conflicts and tensions:

I am now helping one of my colleagues from Belgium who is involved in a conflict. In Belgium, it's normal to report back all information to colleagues on the council. But of course, you cannot simply report back what is happening on the board. (\#39Trade union lawyer representative)

Once established, TBLERs became an effective channel for multilateral knowledge sharing. Through their links to SEWCs, they disseminate managerial knowledge and employee insights to and from subsidiaries and headquarter. Executive managers stressed that internationalizing the board gave it a global perspective. An executive manager of a Germanregistered SE reported that a Polish transnational board-level employee representative ensured that:

[...] see Poland as a cheap production location but as a potential market that requires specific products and market intelligence. This has prompted us to discuss how we can better structure our production network within Europe. (\#22- HR Director) Furthermore, TBLERs brought to headquarters knowledge from subsidiaries that local management might be unwilling to share. The latter 'may say that in a certain country everything is going really, really well, while employee representatives may tell us that things are not going well' (\#22- HR Director).

Overall, the link between the SEWC and TBLERs afforded specific advantages for knowledge sharing. One executive manager described his firm's election process for TBLERs through the SEWC as extremely complex 'but worth doing' (\#27- HR Director). Now with the SEWC, the respondent stated, strong transnational connection has been forged, which the 
former EWC had not achieved. That was vital for the company because ' $[\mathrm{t}]$ he employees and their support play the critical role in our success. In the past it was our assets but today it is the knowledge of employees' (\#27- HR Director).

\section{Discussion}

MNC research debates include attention to transnational employee voice and industrial relations, and to questions of organizational knowledge transfer and optimal utilization across borders. These can entail divergent and conflicting interests among parties. Addressing our research questions, we show that transnational employee voice with works councils and board-level representation, while principally instituted to protect employee interests, can provide avenues for multilateral, multifaceted knowledge exchange in MNCs. The effects of dual-forum transnational employee voice and knowledge sharing actors are multiple and yield a bundle of organizational resources for actor and organizational utility. Our study proposes these effects emerge over time, as transnational employee voice practices in the SE mature, and our Findings section has schematized them as three phases. Specifically the effects are salience for labour interests, building up of competencies among representative actors, better relationships and smoother organization and operations. These occur transnationally and yield intra-company cultural and process qualities, as well as social, labour-interest value. The data shows resulting cross-party recognition of, and joint response to, valuable knowledge, which includes industrial issues at subsidiary level, issues affecting employee welfare and quality of organizational and work life, and insights into countryspecific markets.

Extant studies have shown that building trust and shared identity among transnational labour actors through transnational employee voice strengthens employee voice effectiveness (Cavallini et al., 2015; Lecher et al., 2002; Whittall et al., 2007). Management relations are also identified as vital to sustained trust and cooperation between managers and employees 
and for effective EWC functioning (Mählmeyer et al., 2017; Whittall et al., 2007). Our study concurs. In particular, the data shows that key labour actors play a critical role in building trust among TBLERs and promoting effective practices and processes of employee voice at national subsidiary levels. It also shows their development of affective and cognitive trust among management and fellow employee actors. Their building trust and closer relationships at transnational levels facilitate shared interpretation of problems and mutual interest recognition. As others have found, relationships are crucial but prone to break down in times of crisis (Mählmeyer et al., 2017) or in times of personnel turnover and inexperience of new actors (Hann et al., 2017; Kerckhofs, 2015). Moreover, some managers are reluctant to build relationships with EWCs (Hann et al., 2017), evasive of transnational inclusion and inclined to play national workforces off against each other (Greer and Hauptmeier, 2016). However, our study importantly suggests that the dual roles of SEWCs and TBLERs foster building and sustaining mutual trust and cooperation between SE managers and employees.

Active linkages between the SEWC and boards build relationships and maintain salience of labour and social issues. Both labour and company actors in this study report that sustained relationships of trusted labour actors with management actors affect board-level interactions and influence on decisions. Even as much emphasis in the literature, and in our study, is placed on labour actors gaining competencies for effective participation in transnational employee voice forums, company actors, including managers and executives, also gain knowledge and competencies in regard to employee voice and the value of joint decisions on some issues. Similarly, emphasis is frequently placed on the role of key actors. Yet such individuals may be 'rare and difficult to imitate' (Barner-Rasmussen et al., 2014), posing risk to sustainable voice arrangements if relied on independent of formal voice structures.

Our data indicates that formal transnational employee voice, over time, can diminish reliance on key individual actors. While key actors are likely to remain significant, 
institutionalizing transnational employee voice encourages its normalization and routine recourse in interest expression and decision making. Formal and dual forums of transnational employee voice, when well linked, create organizational pressures - both structural and social - for sharing power and sustaining effort for a culture of cooperation. Effective SEWCs and TBLERs enable highly developed multilateral transnational communication and knowledge exchange across the MNC's workforce. They diffuse multifaceted knowledge across subsidiaries and to and from headquarters. People in sustained communication readily mix productive and relational knowledge sharing in the course of problem solving (Hackman, 2011) and more efficient implementation of organizational operations. Sustained transnational employee voice, our data indicates, builds relationships and social exchange for plural socio-economic benefit.

This study further demonstrates that the role of trade union actors in articulating the linkages and relationships is significant (Pulignano, 2017; Telljohann et al., 2009). Effective boards typically require directors to utilize highly developed technical competencies and industry and international markets knowledge (Kor and Misangyi, 2008; Kroll et al., 2008). Our study shows that beyond those expected competencies, experienced trade union representatives with intensive transnational labour-interest expertise add highly relevant social knowledge to board decision-making. That social knowledge has contributed to addressing employee welfare concerns, avoiding redundancies, redeploying workers, and participating in business model and operational decisions. Föhrer and Erne (2017) have noted in regard to EWCs that unions' training programmes have resulted in limited impact due to a typically narrow pedagogical focus and role conflict of EWC members. However, our findings of high-level competencies evident among experienced TBLERs, elected by SEWCs, in deploying their legal, cultural, and social knowledge of multiple MNCs and accommodating their 'many hats' suggest extensive non-formal learning and networking occurs. This further suggests much scope for strengthening knowledge transfer forums among 
works council actors. Respondents in this study reported evidence of their technical and financial knowledge contributing to SEWC members and workplace labour actors. They also indicated their relationship building efforts to enable greater utilization of transnational employee voice provisions, straddle different roles and foster a shared participatory culture.

All companies in our study had key actors with expertise in national employee voice, and often transnational employee voice through EWCs. They reported sharing their knowledge and expertise with transnational colleagues, many of whom are EWC members but unfamiliar with board-level representation as well as transnational board-level representation. It appears that the SE labour actors, with prior familiarity with board representation in the German context, played significant roles in transnational board-level employee representation initiation and realization. Their expertise is disseminated personally and through European trade unions. This point invites further reflection.

A distinct limitation in this study of SEs must be noted. The SEs of this study, predominantly headquartered in Germany, operate in a specific context characterized by strong national traditions of employee voice. These have influenced the companies' utilization of transnational employee voice and raise important questions regarding the transferability of SE transnational employee voice to other MNCs operating in different contexts. While EWCs occur across all EU member states, and board-level employee representation occurs in 16 EU member states and Norway (Waddington and Conchon, 2016), transnational board representation is rare. Its occurrence is concentrated in SEs. Therefore, we acknowledge that the SE entails a degree of 'specialness', in which both its regulatory framework and frequent historical origins in German employee voice institutions accrue advantages. Numerous studies of MNCs report management under-utilization of voice structures, withholding of information and obstruction (Pulignano and Waddington, 2019; Whittall et al., 2008). Yet our data, reporting predominantly favourable, pro-employee involvement and participation - including transnational composition of boards - and shared 
interest recognition from managers as well as labour actors, runs against the tide.

Significantly, firm actors reported an element of satisfaction in undertaking SE incorporation with dual-forum transnational employee voice. Nonetheless, the low uptake overall in SEs of board-level employee representation requires caution in regard to transferability of our SE findings.

While the SE with dual-forum transnational employee voice remains rare, all of the MNCs in our study are global actors, with significant percentages of employees outside the home country or beyond the EU entirely, as Table 1 profiles. That heft strengthens implications for other MNCs. Even with historical legacies of German institutions, their transnational employee involvement and participation practices indicate that they are not a 'mere international extension of the German codetermination' as Waddington and Conchon's (2017) close study demonstrates, but an institutional innovation of extensive transnational reach. The character of that innovation entails both expansion of transnational employee voice and capacity development of multifaceted knowledge exchange within the EU. The particular qualities of dual-forum transnational employee voice in decision-making bodies lend themselves to multilevel attention to both employee rights and business operational interests. The apparently typically cooperative relations within and between SEWCs and boards, as reported in this study, appear to arise as actors learn elements of cognitive and affective trust over time, and learn the arts of cultural inclusion beyond the headquarter country. These learnings may enable future dispersion beyond the EU of cooperative yet 'sparring partner' relations of mutual recognition as suggested in our study. Assuming uptake of SE incorporation continues, the SE experience may have more transferable learning for other European MNCs as an exemplar of transnational employee voice.

We have to date no data to show effects of transnational employee voice on 'hard' performance measures but clear evidence for its role in organizational social and cultural 
infrastructure crafted over time. Future studies could try to tease out and measure transnational employee voice's effect on MNCs' transnational productivity over time.

\section{Conclusion}

This study of large European MNCs incorporated under the SE regulations and more or less implementing those provisions for extensive transnational employee voice on SEWCs and company boards demonstrates that multiple parties can benefit from co-participation. The article demonstrates that establishing formal transnational employee voice at both works council and board levels in the SE both widens the platform, and strengthens relationships for intra-MNC collaboration. It offers an advance to debates on knowledge sharing that have frequently focussed, in separate forums, on managerial interests in productive capabilities, and on labour interests in protecting employee rights and interests. Multifaceted knowledge sharing brings multiple - social and economic - principles of organizational flourishing into view and pursuit.

The study demonstrates that provision of formal transnational employee voice arrangements builds capacity in the MNC to develop high level competencies including trust among transnational employees and managers. That facilitates multifaceted and multilateral knowledge exchange. The study also shows that while key actors and relationships are significant, so too is the normalization and familiarization of transnational employee voice structures that ensure sustained salience of employee interests and efforts of joint problem addressing.

The European Company (SE) offers a window on how the European Union's most extensive legal provision for employee voice may serve to mutual benefit across company personnel and organizational operations with wide transnational reach. A final word of caution must be recorded. The SE's transnational employee voice provisions are principally, 
and necessarily, instituted for labour's social interest objectives. While the socio-political interactions of transnational employee voice are utilized by diverse transnational actors to learn to share, generate and disperse multifaceted knowledge of value to labour and company interests, enduring responsibility falls to firm and management actors to ensure the integrity of transnational employee voice and avoidance of managerial risk of exploitation of the socially generated flows of rich and diverse knowledge.

\section{References}

Adler PS (2001) Market, hierarchy, and trust: The knowledge economy and the future of capitalism. Organization Science 12(2): 215-34.

Ahlvik C and Björkman I (2015) Towards explaining subsidiary implementation, integration and internalization of MNC headquarters HRM practices. International Business Review 24(3): 497-505.

Baccaro L and Howell C (2017) Trajectories of Neoliberal Transformation: European Industrial Relations since the 1970s. Cambridge: Cambridge University Press.

Barner-Rasmussen W, Ehrnrooth M, Koveshnikov A and Mäkelä K (2014) Cultural and language skills as resources for boundary spanning within the MNC. Journal of International Business Studies 45(7): 886-905.

Belizón MJ (2018) Employee voice in Spanish subsidiaries of multinational firms. European Journal of Industrial Relations 25(1): 75-90.

Bhagat R, Kedia B, Harveston P and Triandis H (2002) Cultural variations in the cross-border transfer of organizational knowledge: An integrative framework. The Academy of Management Review 27(2): 204-21.

Boxall P and Macky K (2009) Research and theory on high-performance work systems: Progressing the high-involvement stream. Human Resource Management Journal 19(1): 3-23. 
Budd JW, Gollan PJ and Wilkinson A (2010) New approaches to employee voice and participation in organizations. Human Relations 63(3): 303-10.

Carley M (2005) Board-level employee representatives in nine countries: A snapshot. Transfer 11(2): 231-43.

Casey C, Fiedler A and Fath B (2016) The European Company (SE): Power and participation in the multinational corporation. European Journal of Industrial Relations 22(1): 7390.

Casey, C (2009) Organizations, workers, and learning: New prospects for citizenship at work? Citizenship Studies 13(2): 169-84.

Cavallini M, Gold M, Royal T and Senatori I (2015) Home country advantage? The influence of Italian, German and Austrian employee representatives in the UniCredit European Works Council. European Journal of Industrial Relations 22(20): 115-30.

Chowdhury S (2005) The role of affect-and cognition-based trust in complex knowledge sharing. Journal of Managerial Issues 17(3): 310-26.

Chua RYJ, Ingram P and Morris MW (2008) From the head and the heart: Locating cognition- and affect-based trust in managers' professional networks. Academy of Management Journal 51(3): 436-52.

Corbin J and Strauss AL (2008) Basics of Qualitative Research: Grounded Theory Procedures and Techniques, 3rd edn. Thousand Oaks, CA: SAGE.

Cremers J, Stollt M and Vitols S (eds) (2013) A Decade of Experience with the European Company. Brussels: ETUI.

Creswell JW (2012) Qualitative inquiry and research design: Choosing among five approaches. Thousand Oaks, CA: SAGE.

De Spiegelaere S and Jagodziński R (2015) European Works Councils and SE Works Councils in 2015. Facts and figures. Brussels: ETUI. 
Edwards T and Edwards MR (2015) Perceptions of employee voice and representation in the post-acquisition period: Comparative and longitudinal evidence from an international acquisition. Human Relations 68(1): 131-56.

Edwards T, Marginson P and Ferner A (2013) Multinational companies in cross-national context: Integration, differentiation, and the interactions between MNCs and nation states. ILR Review 66(3): 547-87.

Eisenhardt KM and Graebner ME (2007) Theory building from cases: Opportunities and challenges. Academy of Management Journal 50(1): 25-32.

Fauver L and Fuerst ME (2006) Does good corporate governance include employee representation? Evidence from German corporate boards. Journal of Financial Economics 82(3): 673-710.

Ferner A, Edwards T and Tempel A (2012) Power, institutions and the cross-national transfer of employment practices in multinationals. Human Relations 65(2): 163-87.

Föhrer B and Erne R (2017) Training programmes for European works councillors in Germany, in Ireland and at EU level: Transnational trade union action through education? European Journal of Industrial Relations 23(3): 243-59.

Geppert M and Williams K (2006) Global, national and local practices in multinational corporations: Towards a sociopolitical framework. The International Journal of Human Resource Management 17(1): 49-69.

Gioia DA, Corley KG and Hamilton AL (2013) Seeking qualitative rigor in inductive research: Notes on the Gioia methodology. Organizational Research Methods 16(1): $15-31$.

Gold M (2011) 'Taken on board': An evaluation of the influence of employee board-level representatives on company decision-making across Europe. European Journal of Industrial Relations 17(1): 41-56. 
Greer I and Hauptmeier M (2016) Management whipsawing: The staging of labor competition under globalization. ILR Review 69(1): 29-52.

Grigoriou K and Rothaermel FT (2014) Structural microfoundations of innovation: The role of relational stars. Journal of Management 40(2): 586-615.

Hackman J (2011) Collaborative intelligence: Using teams to solve hard problems. San Francisco, CA: Berrett-Koehler.

Hann D, Hauptmeier M and Waddington J (2017) European Works Councils after two decades. European Journal of Industrial Relations 23(3): 209-24.

Harzing A-W and Pudelki M (2013) Language competencies, policies and practices in multinational corporations: A comprehensive review and comparison of Anglophone, Asian, Continental European and Nordic MNCs. Journal of World Business 48(1): 87-97.

Hertwig M, Pries L and Rampeltshammer L (2011) Stabilizing effects of European Works Councils: Examples from the automotive industry. European Journal of Industrial Relations 17(3): 209-26.

Hughes M, Powell TH, Chung L and Mellahi K (2017) Institutional and resource-based explanations for subsidiary performance. British Journal of Management 28(3): 40724.

Keller B and Rosenbohm S (2019). The European Company: Original expectations and deficiencies of implementation. European Journal of Industrial Relations. Epub ahead of print 31 January 2019. DOI: 10.1177/0959680118825057.

Keller B and Werner F (2012) New forms of employee involvement at European Level - The case of the European Company (SE). British Journal of Industrial Relations 50(4): 620-43. 
Kerckhofs P (2015) European Works Council developments before, during and after the crisis. Luxembourg: Publications Office of the European Union.

Kim J, MacDuffie JP and Pil FK (2010) Employee voice and organizational performance: Team versus representative influence. Human Relations 63(3): 371-94.

Kochan T and Osterman P (1994) The mutual gains enterprise. Boston, MA: Harvard Business School Press.

Kor YY and Misangyi VF (2008) Outside directors' industry-specific experience and firms' liability of newness. Strategic Management Journal 29(12): 1345-55.

Kroll M, Walters BA and Wright P (2008) Board vigilance, director experience, and corporate outcomes. Strategic Management Journal 29(4): 363-82.

Langley A and Abdallah C (2011) Templates and turns in qualitative studies of strategy and management. In: Bergh D, Ketchen D (eds) Building Methodological Bridges. Bingley: Emerald Group Publishing Limited, 201-35.

Lavelle J, Gunnigle P and McDonnell A (2010) Patterning employee voice in multinational companies. Human Relations 63(3): 395-418.

Lecher W, Platzer HW, Rüb S and Weiner KP (eds) (2002) European Works Councils: Negotiated Europeanisation. Between Statutory Framework and Social Dynamic. Aldershot: Ashgate.

Lee P, Gillespie N, Mann L and Wearing A (2010) Leadership and trust: Their effect on knowledge sharing and team performance. Management Learning 41(4): 473-91.

Lippert I, Huzzard T, Jergens U and Lazonick W (2014) Corporate Governance, Employee Voice, and Work Organization. Oxford: Oxford University Press.

McAllister DJ (1995) Affect- and cognition-based trust as foundations for interpersonal cooperation in organizations. Academy of Management Journal 38(1): 24-59. 
Mählmeyer V, Rampeltshammer L and Hertwig M (2017) European Works Councils during the financial and economic crisis: Activation, stagnation or disintegration? European Journal of Industrial Relations 23(3): 225-42

Marginson P, Hall M, Hoffmann A and Müller T (2004) The impact of European Works Councils on management decision-making in UK and US based Multinationals. British Journal of Industrial Relations 42(2): 209-33.

Marginson P, Lavelle J, Quintanilla J and Adam D (2013) Variation in approaches to European Works Councils in multinational companies. Industrial and Labor Relations Review 66(3): 618-44.

Martin JA, and Eisenhardt KM (2010) Rewiring: Cross-business-unit collaborations in multibusiness organizations. Academy of Management Journal 53(2): 265-301.

Martin-Perez V and Martin-Cruz N (2015) The mediating role of affective commitment in the rewards-knowledge transfer relation. Journal of Knowledge Management 19(6): $1167-85$.

Minbaeva D, Pedersen T, Björkman I, Fey CF and Park HJ (2003) MNC knowledge transfer, subsidiary absorptive capacity and HRM. Journal of International Business Studies 34(6): 586-99.

Morgan G and Kristensen PH (2006) The contested space of multinationals: Varieties of institutionalism, varieties of capitalism. Human Relations 59(11): 1467-90.

Mudambi R and Swift T (2011) Leveraging knowledge and competencies across space. Journal of International Management 17(3): 186-89.

Nahapiet and Goshal (1998) Social capital, intellectual capital, and organizational advantage. Academy of Management Review 23(2): 242-66.

Peltokorpi V (2015) Corporate language proficiency and reverse knowledge transfer in multinational corporations. Journal of International Management 21(1): 49-62. 
Platzer HW and Rüb S (2014) It takes two to tango: Management and European company agreements. Transfer 20(2): 255-70.

Pulignano V (2017) Articulation within (and across) transnational workplaces and the role of European Works Councils. European Journal of Industrial Relations 23(3): 261-76.

Pulignano V and Waddington, J (2019) Management, European Works Councils and institutional malleability European Journal of Industrial Relations: 1-17. DOI: $10.1177 / 0959680118824512$.

Rosenbohm S (2013) Verhandelte Arbeitnehmerbeteiligung: Ein empirischer Vergleich der Formen vor und nach der Gründung einer Europäischen Aktiengesellschaft. Industrielle Beziehungen 20(1): 8-35.

Schotter A and Beamish PW (2011) Performance effects of MNC headquarters-subsidiary conflict and the role of boundary spanners. Journal of International Management 17(3): $243-59$.

Stollt M and Kluge N (2011) The potential of employee involvement in the SE to foster the Europeanization of labour relations. Transfer: European Review of Labour and Research 17(2): 181-91.

Swift PE and Hwang A (2013) The impact of affective and cognitive trust on knowledge sharing and organizational learning. The Learning Organization 20(1): 20-37.

Telljohann V, Da Costa I, Müller T, Rehfeldt U and Zimmer R (2009) European and international framework agreements: New tools of transnational industrial relations. Transfer 15(3-4): 505-25.

Tempel A, Edwards T, Ferner A, Muller-Camen M and Wächter H (2006) Subsidiary responses to institutional duality: Collective representation practices of US multinationals in Britain and Germany. Human Relations 59(11): 1543-70.

Urquhart C (2013) Grounded theory for qualitative research: A practical guide. SAGE. 
Waddington J (2010) European Works Councils and Industrial Relations. New York, NY: Routledge.

Waddington J and Conchon A (2016) Board-level Employee Representation in Europe: Priorities, Power and Articulation. New York, NY: Routledge.

Waddington J and Conchon A (2017) Is Europeanised board-level employee representation specific? The case of European Companies (SEs). ETUI Research Paper-Working Paper. Available at SSRN: http://dx.doi.org/10.2139/ssrn.2989460

Wang S and Noe R (2010) Knowledge sharing: A review and directions for future research. Human Resource Management Review 20(2): 115-31.

Weiß D (2016) Arbeitnehmermitbestimmung und die Europäische Aktiengesellschaft (SE): Eine empirische Analyse auf Länderebene. German Journal of Human Resource Management 30(2): 84-107.

Welch DE and Welch LS (2008) The importance of language in international knowledge transfer. Management International Review 48(3): 339-60.

Whittall M, Knudsen H and Huijgen F (eds) (2007) Towards a European Labour Identity. London: Routledge.

Whittall M, Lücking S and Trinczek R (2008) Understanding the European Works Council deficit in German multinationals. Transfer 14(3): 453-68.

Whittall M, Lücking S and Trinczek R (2009) The frontiers within: Why employee representatives fail to set up European Works Councils. Industrial Relations Journal 40(6): 546-62. 
Table 1: Overview of SEs and interviewees

\begin{tabular}{|c|c|c|c|c|c|c|c|}
\hline \multirow[t]{2}{*}{ SE } & \multirow{2}{*}{$\begin{array}{l}\text { Number } \\
\text { employees } \\
\text { (total) }\end{array}$} & \multicolumn{3}{|c|}{ \% Employees' } & \multirow{2}{*}{$\begin{array}{l}\text { Turn- } \\
\text { over in } \\
\text { Euro }\end{array}$} & \multirow{2}{*}{$\begin{array}{l}\text { Management } \\
\text { perspective - } \\
\text { Interviews }\end{array}$} & \multirow{2}{*}{$\begin{array}{l}\text { Employee perspective - } \\
\text { Interviews }\end{array}$} \\
\hline & & $\begin{array}{l}\text { Home } \\
\text { country }\end{array}$ & $\begin{array}{l}\text { Within } \\
\text { EU (excl. } \\
\text { home } \\
\text { country) }\end{array}$ & $\begin{array}{l}\text { Outside } \\
\text { EU }\end{array}$ & & & \\
\hline \multirow[t]{3}{*}{1} & \multirow[t]{3}{*}{$>100,000$} & \multirow[t]{3}{*}{30} & \multirow[t]{3}{*}{40} & \multirow[t]{3}{*}{30} & \multirow{3}{*}{$\begin{array}{l}>50 \\
\text { billion }\end{array}$} & \#2 HR Director & \multirow{3}{*}{$\begin{array}{l}\text { \#3 I rade union, board } \\
\# 1 \text { SEWC, board }\end{array}$} \\
\hline & & & & & & $\begin{array}{l}\text { \#4 Company } \\
\text { lawyer }\end{array}$ & \\
\hline & & & & & & $\begin{array}{l}\text { \#6 } \\
\text { CEO/Chairman* }\end{array}$ & \\
\hline \multirow[t]{2}{*}{2} & \multirow[t]{2}{*}{$>100,000$} & \multirow[t]{2}{*}{50} & \multirow[t]{2}{*}{10} & \multirow[t]{2}{*}{40} & \multirow[t]{2}{*}{$\begin{array}{l}20-50 \\
\text { billion }\end{array}$} & $\begin{array}{l}\text { \#6 Supervisory } \\
\text { board* }\end{array}$ & \#7 SEWC, board \\
\hline & & & & & & $\begin{array}{l}\text { \#9 Company } \\
\text { lawyer }\end{array}$ & \#8 Trade union, board \\
\hline \multirow[t]{3}{*}{3} & \multirow[t]{3}{*}{$>100,000$} & \multirow[t]{3}{*}{40} & \multirow[t]{3}{*}{10} & \multirow[t]{3}{*}{50} & \multirow{3}{*}{$\begin{array}{l}>50 \\
\text { billion }\end{array}$} & \#5 HR Director & \#11 SEWC, board \\
\hline & & & & & & \multirow{2}{*}{$\begin{array}{l}\text { \#45 Executive - } \\
\text { legal }\end{array}$} & \#12 SEWC \\
\hline & & & & & & & \#10 Trade union, board \\
\hline 4 & $\begin{array}{l}3,000- \\
10,000\end{array}$ & 50 & 20 & 30 & $\begin{array}{l}<1 \\
\text { billion }\end{array}$ & $\begin{array}{l}\text { \#13 } \\
\text { CEO/Chairman }\end{array}$ & \\
\hline \multirow[t]{2}{*}{5} & \multirow[t]{2}{*}{$\begin{array}{l}50,000- \\
100,000\end{array}$} & \multirow[t]{2}{*}{10} & 70 & 20 & $\begin{array}{l}10-20 \\
\text { billion }\end{array}$ & $\begin{array}{l}\text { \#14 Executive - } \\
\text { international }\end{array}$ & \#15 Trade union, board \\
\hline & & & & & & \#16 Consultant & \\
\hline 6 & 10,000 & 30 & 60 & 10 & & \#18 HR Director & \#17 Trade union, board \\
\hline & 50,000 & & & & billion & $\begin{array}{l}\text { \#19 Executive - } \\
\text { legal }\end{array}$ & \\
\hline 7 & 50,000 & 60 & 30 & 10 & $10-20$ & \#22 HR Director & \#20 SEWC \\
\hline & 100,000 & & & & billion & $\begin{array}{l}\text { \#23 Company } \\
\text { lawyer }\end{array}$ & \#21 Trade union, board \\
\hline 8 & 50,000 & 20 & 40 & 40 & & \#24 Executive & \#25 SEWC \\
\hline & 100,000 & & & & billion & legal & \#26 SEWC \\
\hline 9 & 10,000 & 40 & 40 & 20 & $20-50$ & \#27 HR Director & \#28 Trade union, board \\
\hline & 50,000 & & & & billion & & \#29 Trade union, board \\
\hline 10 & 3,000 & 30 & 40 & 30 & $1-5$ & \#31 HR Director & \#30 SEWC \\
\hline & 10,000 & & & & billion & & \#32 SEWC, board \\
\hline 11 & $\begin{array}{l}3,000- \\
10,000\end{array}$ & 40 & 60 & - & $\begin{array}{l}1-5 \\
\text { billion }\end{array}$ & $\begin{array}{l}\text { \#34 Company } \\
\text { lawyer }\end{array}$ & \#33 SEWC, board \\
\hline 12 & 3,000 & 30 & 30 & 40 & $1-5$ & \#36 HR Director & \#35 SEWC \\
\hline & 10,000 & & & & billion & & \#37 SEWC \\
\hline & & & & & & & \#38 SEWC \\
\hline 13 & $10,000-$ & 50 & 40 & 10 & $1-5$ & \#41 Executive & \#39 Trade union, board \\
\hline & 50,000 & & & & billion & legal & \#40 SEWC, board \\
\hline & & & & & & & Expert interviews \\
\hline & & & & & & & \#42 Trade union lawyer \\
\hline & & & & & & & $\begin{array}{l}\text { \#44 EU trade union } \\
\text { official }\end{array}$ \\
\hline & $\begin{array}{l}\text { ercentages ha } \\
\text { interview }\end{array}$ & been rou & nded to the & earest te & (based & 5 data). & $\begin{array}{l}\text { \#43 EU trade union } \\
\text { expert }\end{array}$ \\
\hline
\end{tabular}


Figure 1: Raising transnational employee voice through SE phases and effects on knowledge sharing

Phase 1: Employee voice and SE Phase 2: SEWC and transnational Phase 3: Transnational employee voice, initiation knowledge sharing knowledge sharing and board relationships

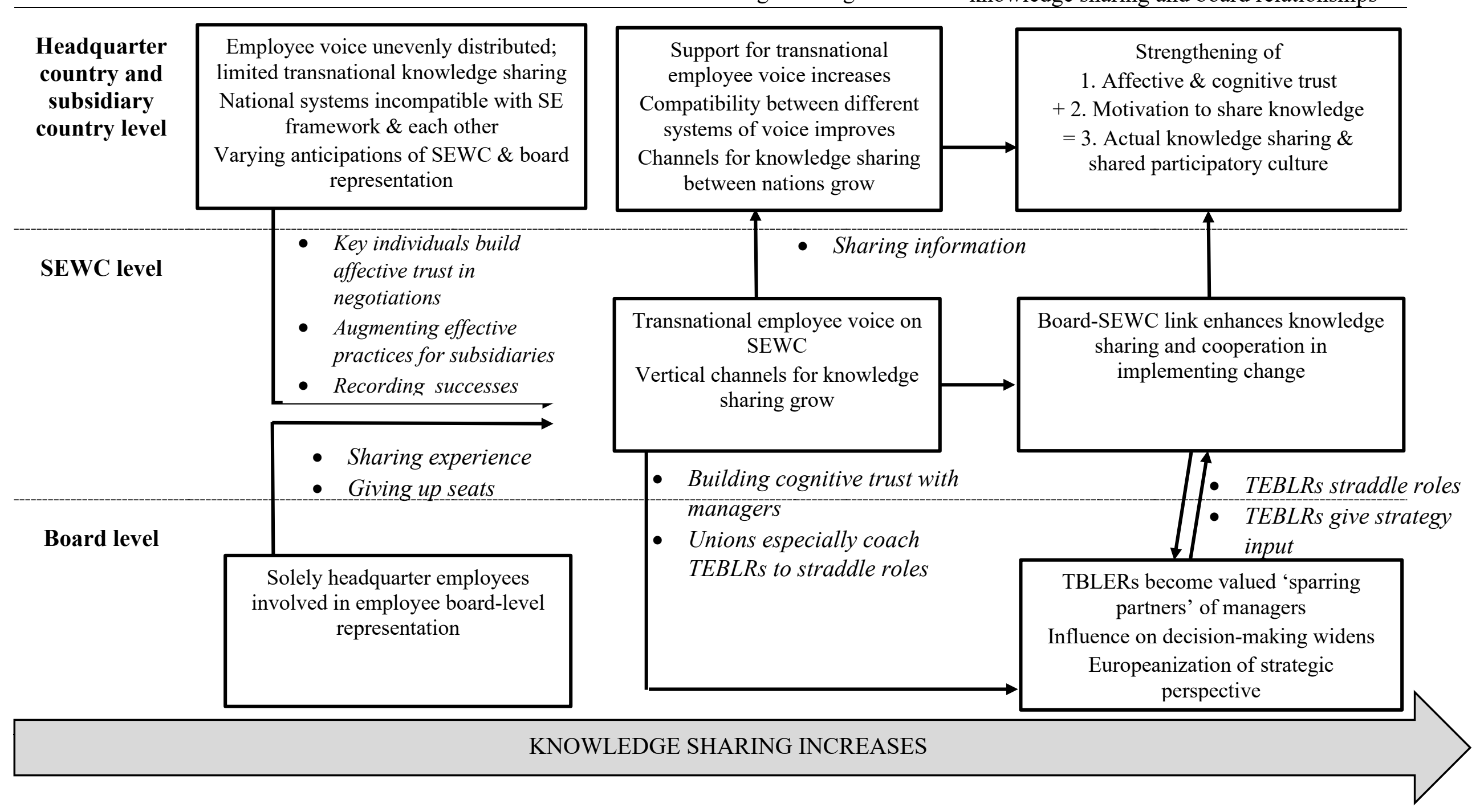




\section{Barriers to multilateral knowledge sharing in Phase 1 employee voice and SE initiation}

Lack of compatibility between different voice systems

The participation on the board is complicated, most of the countries don't understand the system. [...] for international colleagues, this is a new experience that is somewhat strange for them; it takes a long time for most of them to understand their role. $(\# 1)$

When you look at the French, they will strike about every little thing, trade unions are very powerful there; we aren't very familiar with that in the Netherlands. (\#38)

Strong influence headquarters; voice unevenly distributed We, from the headquarters, always had a relatively good relationship with the managers. (\#26)

The people in Germany are close to the headquarters; they had more information than we had from the foreign countries ... you see that people from Germany at the beginning wanted to do it themselves. (\#30)

Lack of compatibility between different voice systems

If somebody comes from a country with almost no, or only weak, structures for employee voice, [it's hard] to explain the benefits to this person.' (\#42)

The non-German delegates don't have a lot of prior knowledge. So, we cannot expect that strong employee representatives will join the board, but rather that the stronger German representatives will be weakened. (\#29)

Strong influence headquarters; voice unevenly distributed I think it is important that we now do not just consider the interests of the German plants, but also consider the interests of the international plants. (\#21)

We look at the meetings what is happening in different subsidiaries. What was noticeable is that the reporting across subsidiaries was very much disorganized. (\#29)
Lack of compatibility between different voice systems

Initially, the Czech representative [on the SEWC] was only concerned about what was happing in his country. The same was true for the Romanian, the Polish, the French, the Irish, etc. (\#3)

We supported training courses offered by the trade union because we could see how diverse backgrounds of employee representatives actually were. (\#2)

Strong influence headquarters; voice unevenly distributed Smaller countries with relatively few employees felt isolated and not well integrated. Some of them did not even have their own works council. (\#13)

We already had an EWC, but the employee voice was very much dominated by the German representatives. And they did not have enough consideration for the needs of smaller countries. (\#27)

Change mechanisms for overcoming barriers and improving transnational employee voice in Phases 2 and 3 of SE

\section{Building trust}

We have an interest in keeping potential attacks on managers from our people in check. We want positive relations. We have no interest in confronting the managers unconstructively. (\#26)

Now, through [transnational] meetings, we [the SEWC] have become much closer. We work collectively to achieve a common goal, we are united ... we have become a small community, and friendships have evolved. (\#33)

\section{Augmenting of practices for compatibility}

We had to understand the differences between the systems first. What is the legal background in Poland, and so on. We put this all in a matrix, and we discussed on the SEWC the differences, to understand the practices that exist, and how they relate to countries. [...] in some instances, we converged some of the practices to be better aligned with the SEWC. (\#40)
Building trust

We can resolve issues now because the people know each other and trust each other. (\#10)

For most of the issues that we had to consider, we had to rely on a gut feeling, and the legal foundation did not matter very much. (\#21)

\section{Augmenting of practices for compatibility}

We organized a seminar for employee board representatives outside of Germany, we did study some of the laws and regulation, but we also talked a lot about the purpose of it, the different role expectations, what can I do and what is not allowed. How can we connect the SEWC and the board, and how do I wear these different hats for these roles? (\#42)
Building trust

The advantage is that people [at transnational level] get to know each other, not only the management but also the employees. They talk to each other ... and develop a shared understanding of the business. (\#4)

It is important to establish trust. If I [CEO] participate and get across the advantages and objectives, I can help the employee representatives, because they trust that this is something positive for the future of the company. (\#13)

\section{Augmenting of practices for compatibility}

If the French, let's say, would try to introduce their style, they would upset the other Europeans, who are as a whole very constructive. They would not be able to push such an agenda. (\#36) 


\begin{tabular}{|c|c|c|}
\hline EMPLOYEES & TRADE UNION OFFICIALS & MANAGERS \\
\hline Augmenting of practices for compatibility (continued) & Augmenting of practices for compatibility (continued) & Augmenting of practices for compatibility (continued) \\
\hline $\begin{array}{l}\text { For the French, the concept of a social partnership is a different } \\
\text { world. They had to understand the scope of consultation rights and } \\
\text { the opportunities resulting from them. (\#25) }\end{array}$ & $\begin{array}{l}\text { We agreed on a template that everyone can use with headings in } \\
\text { German, English and French, and colleagues all over Europe } \\
\text { provide information systematically and present it, including the } \\
\text { economic situation in Europe, in different countries. (\#29) }\end{array}$ & $\begin{array}{l}\text { In France, there is a strong national interest, and they also like to } \\
\text { confront us. There was a strong personality on the board who } \\
\text { focused on national themes. But luckily, we could educate this } \\
\text { person over time. (\#41) }\end{array}$ \\
\hline Sharing success stories & Straddling of roles - Preparation & Embracing a European perspective \\
\hline $\begin{array}{l}\text { The French colleagues did not have a work council on the national } \\
\text { level. We explained this concept to them and then introduced [a } \\
\text { country-wide work council] in France. By doing so, we brought } \\
\text { some of the French locations together for the first time. (\#40) }\end{array}$ & $\begin{array}{l}\text { We offered a seminar for [TBLERs] outside of Germany, we } \\
\text { studied laws and regulation; we talked about the purpose of it; } \\
\text { different role expectations, what can I do; what is not allowed. } \\
(\# 42)\end{array}$ & $\begin{array}{l}\text { We have an opportunity to get a second perspective on issues. } \\
\text { Local managers may say that in a certain country everything is } \\
\text { going really well, while employee representatives may say that } \\
\text { things are not going well ... (\#22) }\end{array}$ \\
\hline $\begin{array}{l}\text { 'In Greece, we had a crisis, and the SEWC was trusted with } \\
\text { discussing it...' The outcome was that, 'even though the revenue } \\
\text { had halved, no redundancies were made. So we are not just } \\
\text { focusing on cross-border issues, we also look at specific country } \\
\text { cases.' (\#35) }\end{array}$ & $\begin{array}{l}\text { At a seminar for [TBLERs] we studied law and regulation, } \\
\text { talked about different role expectations, what is allowed or not } \\
\text { allowed. How can we connect the SEWC and the board; how do } \\
\text { I wear these different hats? (\#44) }\end{array}$ & $\begin{array}{l}\text { The international employee representatives' voice was heard } \\
\text { much more through this process. They are highly engaged and } \\
\text { now our board is highly internationalized. We've had a drastic } \\
\text { change, with real leadership of employee voice in the company. } \\
\text { (\#27) }\end{array}$ \\
\hline \multicolumn{3}{|c|}{ Effects of dual-forum transnational employee voice and knowledge sharing actors } \\
\hline $\begin{array}{l}\text { Effective transnational employee voice for knowledge sharing } \\
\text { We now have contact with other European countries and } \\
\text { understand better how the MNC operates. We have a strong global } \\
\text { focus and understand how cross-border strategies are } \\
\text { implemented. This form of exchange of information is new and } \\
\text { positive for all sides. The board now receives information from } \\
\text { [EU] employees first hand. (\#26) } \\
\text { The participation within the EU, has been improved significantly } \\
{[\ldots . .] \text { the culture is more open, nothing is really a secret anymore, }} \\
\text { e.g., economic data and middle term planning, such as five-year } \\
\text { investment plans. (\#30) }\end{array}$ & $\begin{array}{l}\text { Effective transnational employee voice for knowledge } \\
\text { sharing } \\
\text { Employees working in smaller [transnational] subsidiaries } \\
\text { receive valuable information first hand, even when they are not } \\
\text { able to participate directly in the SEWC. (\#28) } \\
\text { Due to the efforts of two employee representatives on the } \\
\text { SEWC, a culture has been established within the company that } \\
\text { fosters information flow across the company that goes far } \\
\text { beyond the legally required information provision. (\#15) }\end{array}$ & $\begin{array}{l}\text { Effective transnational employee voice for knowledge } \\
\text { sharing } \\
\text { The number on the board is limited, currently we have German } \\
\text { and French [TBLERs]; they represent Holland, Sweden, Italy } \\
\text { and so on [...] but they can take the information to the SEWC, } \\
\text { and we time these two meetings well; about a week after the } \\
\text { board meeting to allow them to disseminate the information } \\
\text { about future plans. This is an important multiplier for } \\
\text { transparency in decisions. (\#41) } \\
\text { Change can only be effectively implemented when there is a } \\
\text { fundamental agreement between employees and management. } \\
\text { We can make decisions, but if nobody supports these decisions, } \\
\text { they are meaningless. (\#6) } \\
\text { Influence in decision-making widens } \\
\text { The SEWC is now completely involved in all cross-border } \\
\text { activities ... They have established working groups that take part } \\
\text { in all the company's business. (\#18) } \\
\text { We receive information through the SEWC. We want to ensure } \\
\text { that the interests of the employees are considered, but we also } \\
\text { want to have information. A lot of information now comes from } \\
\text { individual countries which we can access through the SEWC. } \\
\text { (\#36) }\end{array}$ \\
\hline
\end{tabular}

